\title{
脳梗塞に合併した脳動脈瘤の治療
}

\author{
小川 彰, 藤本 俊一, 白根 礼 造, 桜 井 芳 明 \\ 嘉山 孝 正, 佐 藤 博 雄, 杉田 京一
}

\section{Treatment of Intracranial Aneurysms Associated with Cerebral Infarction}

Akira OGawa, M.D., Shunichi Fujimoto, M.D., Reizou Shirane, M.D., Yoshiharu Sakurai, M.D., Takamasa Kayama, M.D., Hiroo Sato, M.D., and Kyouichi Sugita, M.D.

Department of Neurosurgery, Stroke Center, Sendai National Hospital, Sendai, Japan

Summary : Twenty-four cases of intracranial aneurysms associated with cerebral infarction were studied. The types of infarction were as follows: Five cases of TIA, five of RIND and fourteen completed strokes. Ten cases had unruptured aneurysms and fourteen cases had ruptured aneurysms. Aneurysm surgery was performed in fifteen out of twenty four cases. EC-IC bypass or carotid endarterectomy for the responsible occlusive vascular lesion was performed in five cases. Operative results on discharge were as follows: Eight cases showed excellent results, two good, four fair and one poor. Operative complication was observed in only case. This was the occlusion of the perforating branch of the middle cerebral artery caused by the neck clipping of the aneurysm. The operative results were not as bad as in previous reports, which would seem to indicate that revascularization can be useful for preventing postoperative ischemic complications.

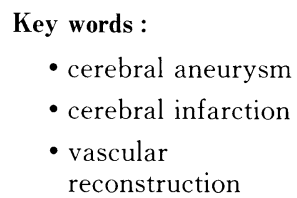

\section{はじめに}

脳動脈瘤症例において，脳梗塞の既往を有する例や，閉 塞性血管病変を有する症例では, 術後の合併症発現頻度が 高く，予後に影響するため手術適応は慎重にすべきとの考 えがある。しかし，このような症例の治療方針や治療成績 に関する報告は少なくいまだ十分な検討がなされていない. われわれは脳梗塞合併例においても，術前の状態が良好な 症例に対しては積極的に脳動脈瘤根治術を施行する方針を とってきた．本報では自験24例について検討を行い，その 結果から治療方針について述べる。

\section{対 象}

1978年 4 月以降，当科にて経験した脳梗塞動脈瘤合併例 24例を対象とした．性別は男性13例，女性11例，年齢分布
は33歳から71歳まで，平均61歳であった。また既往歴では 高血圧症16例, 糖尿病 9 例, 虚血性心疾患 4 例などが認め られた。

対象症例の脳梗塞の発症様式は, TIA 5 例, RIND 5 例, completed stroke 14例であった。脳血管撮影は原則と して 4-vessels study を全例に施行した。主幹脳動脈の動 脈硬化性変化は22例に認められ，脳梗塞の責任病変として 血管の閉塞，高度の狭窄などの所見は11例で観察された。 病変部位は頸部内頸動脈 3 例, 頭蓋内内頸動脈 3 例, 中大 脳動脈 5 例であった．動脈硬化などの血管変化も認められ なかった 2 例はともに心疾患を有し，心由来の塞栓が脳梗 塞の原因と考えられた症例であった。脳動脈瘤の部位は前 交通動脈瘤 7 例, 内頸動脈瘤 5 例, 中大脳動脈瘤 6 例, 前 大脳動脈瘤 1 例, 多発性動脈瘤 3 例であった。

これらの24例は脳梗塞の既往がある破裂動脈瘤症例14例 
Table 1

\begin{tabular}{|c|c|c|c|c|c|c|c|c|}
\hline No. & Age & Sex & Infarction & Vascular leision & Aneurysm & Grade & Operation & $\begin{array}{l}\text { Results on } \\
\text { discharge }\end{array}$ \\
\hline 1 & 64 & M & lt TIA & lt ICA occlusion & rt ICA & II & $\begin{array}{l}\text { clipping } \\
\text { STA-MCA bypass }\end{array}$ & Ex \\
\hline 2 & 53 & M & lt TIA & lt ICA stenosis & $A \operatorname{com} A$ & III & $\begin{array}{l}\text { clipping } \\
\text { endarterectomy }\end{array}$ & Ex \\
\hline 3 & 66 & $\mathrm{~F}$ & lt $\mathrm{mCST}$ & sclerosis & lt ICA & I & clipping & Ex \\
\hline 4 & 68 & $\mathrm{~F}$ & lt TIA & lt ICA stenosis & multiple & II & $\begin{array}{l}\text { clipping } \\
\text { endarterectomy }\end{array}$ & Ex \\
\hline 5 & 59 & M & lt RIND & blt ICA stenosis & multiple & II & $\begin{array}{l}\text { clipping } \\
\text { STA-MCA bypass }\end{array}$ & Ex \\
\hline 6 & 67 & M & vert TIA & sclerosis & $A \operatorname{com} A$ & III & clipping & $\mathrm{F}$ \\
\hline 7 & 67 & $\mathrm{~F}$ & It CST & It MCA occlusion & lt ICA & III & clipping & $\mathrm{F}$ \\
\hline 8 & 66 & M & rt TIA & sclerosis & It MCA & II & clipping & $\mathrm{F}$ \\
\hline 9 & 63 & M & rt CST & no & rt ACA & II & clipping & $\mathrm{P}$ \\
\hline 10 & 71 & $\mathrm{~F}$ & rt RIND & rt MCA occlusion & lt ICA & II & $(-)$ & $\mathrm{F}$ \\
\hline 11 & 66 & M & lt CST & sclerosis & It ICA & IV & $(-)$ & $\mathrm{D}$ \\
\hline 12 & 33 & $\mathrm{~F}$ & lt CST & no & lt $\mathrm{MCA}$ & IV & $(-)$ & $\mathrm{D}$ \\
\hline 13 & 62 & $\mathrm{~F}$ & rt CST & sclerosis & $A \operatorname{com} A$ & IV & $(-)$ & $\mathrm{D}$ \\
\hline 14 & 38 & M & It TIA & lt ICA occlusion & A com A & V & $(-)$ & $\mathrm{D}$ \\
\hline
\end{tabular}

Table 2

\begin{tabular}{|c|c|c|c|c|c|c|c|}
\hline No. & Age & Sex & Infarction & Vascular leision & Aneurysm & Operation & $\begin{array}{c}\text { Results on } \\
\text { discharge }\end{array}$ \\
\hline 1 & 67 & $\mathrm{~F}$ & rt CST & sclerosis & multiple & clipping & Ex \\
\hline 2 & 56 & M & rt RIND & sclerosis & multiple & clipping & Ex \\
\hline 3 & 67 & M & $\mathrm{rt} \mathrm{mCST}$ & rt ICA stenosis & rt $\mathrm{MCA}$ & $\begin{array}{l}\text { clipping } \\
\text { endarterectomy }\end{array}$ & Ex \\
\hline 4 & 66 & $\mathrm{~F}$ & It RIND & sclerosis & lt $\mathrm{MCA}$ & clipping & G \\
\hline 5 & 62 & $\mathrm{~F}$ & blt mCST & sclerosis & lt $\mathrm{MCA}$ & clipping & G \\
\hline 6 & 60 & M & blt CST & sclerosis & rt $\mathrm{MCA}$ & clipping & $\mathrm{F}$ \\
\hline 7 & 68 & $\mathrm{~F}$ & It $\operatorname{CST}$ & lt ICA stenosis & multiple & $(-)$ & $\mathrm{F}$ \\
\hline 8 & 60 & $\mathrm{~F}$ & rt CST & sclerosis & $A \operatorname{com} A$ & $(-)$ & $\mathrm{P}$ \\
\hline 9 & 60 & M & rt CST & lt MCA stenosis & $A \operatorname{com} A$ & $(-)$ & $\mathrm{P}$ \\
\hline 10 & 56 & M & blt CST & lt MCA stenosis & $\mathrm{A} \operatorname{com} \mathrm{A}$ & $(-)$ & $\mathrm{P}$ \\
\hline
\end{tabular}

(以下, 破裂動脈瘤群) と, 脳梗塞で来院し偶然に未破裂動 脈瘤が発見された10例 (以下, 未破裂動脈瘤群)に分類され た.

破裂動脈瘤群14例 (Table 1) のうち, 脳動脈瘤根治術が施 行されたのは 9 例で，おの㧈のの症例の入院時 Hunt \& Kosnik grade は I が 1 例, II が 5 例, IIIが 3 例であった. また非手術例は 5 例で, それらの入院時 grade は II が 1 例, INが 3 例, Vが1例であった.

未破裂動脈瘤群10例 (Table 2)のうち, 脳動脈瘤根治術が なされたのは一般状態が良好であった 6 例で，非手術例 4 例は脳梗塞による神経脱落症状が重篤であったり，心疾患 などの合併症により全身状態が不良の症例であった。

\section{結 果 (Table 1,2)}

\section{1. 破裂動脈瘤群}

動脈瘤根治手術施行例 9 例の退院時成績は, excellent 5 例, fair 3 例, poor 1 例で死亡例はなかった. 入院時 grade 別では, I の 1 例が excellent であり， II の 5 例で は excellent 3 例, fair 1 例, poor 1 例であり, grade III で手術した 3 例では, excellent 1 例, fair 2 例であった.

Fair, poor の予後不良となった 4 例では脳虚血に対する 血行再建術は行わず動脈瘤根治術のみの施行例であった. これらの症例の予後不良因子であるが, Case 6では発症時 の CT 上 diffuse な $\mathrm{SAH} に$ 加え ICH を伴い primary brain damageによるものであり, Case 9 では術後のmeningitis の合併により状態が悪化した例であり, Case 7 と8では 
spasmにより神経症状が悪化した例であった。これに対し て, 脳動脈瘤根治術に加え, 脳虚血に対する血行再建術が 施行された 4 例はいずれも良好な成績が得られた。

また，非手術 5 例のうち入院時 grade が $\mathrm{N}$ 〜 Vで手術適 応外であった 4 例は動脈瘤根治手術に至らずいずれも死亡 した。また入院時 grade II であった 1 例は高齢および全身 状態不良のため手術適応外とした症例であるが失見当識の ためfairで退院した。

\section{2. 未破裂動脈瘤群}

未破裂動脈瘤群では入院時の神経症状が軽度であった 6 例に対し動脈瘤根治手術を行った。 6 例のうち脳虚血発作 の責任血管病変が明らかだった頸部内頸動脈狭窄症例 (Case 3) に対しては頸動脈血栓膜剥離術もあわせて行った. 手術例 6 例の退院時成績は excellent 3 例, good 2 例, fair 1 例であった. 手術により, 症状が悪化した症例が 1 例 (Case 6) あり，この症例では右中大脳動脈瘤柄部 clippingに際して穿通枝の閉塞をきたし，左片麻痺が発現し た症例であった。

\section{考察}

脳梗塞の既往がある脳動脈症例は，基礎疾患として動脈 硬化性病変, 高血圧症, 糖尿病などを有する場合が多く, 術後には脳虚血による機能障害が発生したり脳内出血を合 併する頻度が高く予後不良な場合が多いため, 手術適応は 慎重にすべきであるという考えがある，北原ら ${ }^{1)}$ は，脳梗 塞に合併した未破裂動脈瘤手術例20例中，16例に術後合併 症が発現し， 7 例で症状の増悪をきたしたと報告している. しかし，われわれは脳梗塞合併症といえども一般状態が良 好な症例に対しては積極的に脳動脈瘤根治術を施行する方 針をとってきた。

われわれの手術適応の原則は, 通常の破裂脳動脈瘤の適 応に準じ, 年齢は70歳以下, 術前 grade $\mathrm{Na}$ までとし, 脳 虚血発作が TIA か, RIND あるいは minor completed stroke で脳梗塞による神経脱落症状が軽微で, 責任血管病 変の明らかな症例に対しては血行再建術をあわせて行うも のである。また，未破裂動脈瘤も上記適応に準じた。

結果は脳梗塞に脳動脈瘤を合併した24例中, 15例に動脈 瘤根治術を施行し, 術前より, 術後症状が悪化した例は 1 例のみで, 比較的良好な成績が得られている，特に，血行 再建術を動脈瘤根治術に加えて施行した 5 例では, その後 の follow-up でも再発なく良好な経過であった.

さて, 術後に症状が悪化した 1 例は未破裂中大脳動脈瘤 例で中大脳動脈に加え動脈瘤自体に著明な動脈硬化が認め られた症例で, body clip で処置したものであるが, 術後
穿通枝領域の LDA が出現し麻痺の残った例である．手術 に際しては，麻酔時の低血圧による脳灌流圧低下や，静脈 の温存, 脳圧排に伴う合併症に対する注意は無論のこと, 動脈硬化性変化が高度であることを留意し種々の注意が必 要である ${ }^{2)}$. 脳動脈瘤柄部周囲に高度の動脈硬化性变化が 認められる場合は動脈の kink を避けるべく柄部 clipping は断念し, 動脈瘤全貌を露出後完全な wrapping を行うな どの工夫が必要である。また動脈硬化の強い血管からの小 動脈枝は容易に閉塞するので特に愛護的に操作するべきで ある．以上の点に留意し手術を行うことによって術後合併 症が避けられ良好な予後が期待できると考えられた。

また, 破裂脳動脈瘤例において, 既往の脳虚血発作の狭 窄, 閉塞などの責任血管病変が明らかな例における血行再 建術の施行時期であるが，本シリーズの破裂右内頸動脈瘤 症例において脳血管攣縮期に既存の内頸動脈閉塞側の大脳 半球症状の TIA が頻発し, 直ちにSTA-MCA 吻合術を行 い症状軽快をみた症例があり，本例においては，脳梗塞の 責任血管病変に加え脳血管攣縮が脳灌流圧の減少をきたし 症状を発現させたと考えられた。このように, 既存の閉塞 性病変を治療せずにおくことは脳血管攣縮期に症状覀化の 誘因となりうると考えられ, 特に破裂動脈瘤症例で閉塞性 血管病変が明らかな症例に対しては, 急性期の破裂脳動脈 瘤根治手術施行時に同時に血行再建術を行うべきであると 考えられた。

未破裂動脈瘤の手術適応であるが, 未破裂動脈瘤からの 小血栓が脳梗塞を起こしたと考えられる例 ${ }^{3) 45)}$ の報告や， 未破裂動脈瘤がクモ膜下出血を引き起こす risk は高いと の指摘もあり (6)7)8)，積極的に脳動脈瘤根治術を行うべき との考えもある. しかし, 未破裂動脈瘤は通常の囊状脳動 脈瘤のみならず動脈硬化性動脈瘤が多く含まれており,こ の点, 手術の risk は高く, 年齢や全身状態さらに脳血管 撮影所見などを総合的に判断し, 慎重に決定すべきである と考えられた。

\section{文献}

1）北原茂美, 斉藤 勇, 瀬川 弘, 仁瓶博夫, 岡田 崇: 脳梗 塞に合併した脳動脈瘤の手術. 第12回脳卒中の外科研究会講 演集，にゅーろん社，東京，1983，pp 165-168

2）畑中光昭, 児玉南海雄, 桜井芳明, 鈴木二郎: 老年者囊状動 脈瘤の手術. 脳神経外科 7:229-232, 1979

3) Fukuoka S, Suematsu K, Nakamura J, Matsuzaki T, Satoh S, Hashimoto I: Transient ischemic attacks caused by unruptured intracranial aneurysm. Surg Neurol 17: 464-467, 1981

4) Hoffman WF, Wilson CB, Townsend JJ: Recurrent transient ischemic attacks secondary to an embolizing saccular middle cerebral artery aneurysm. J Neurosurg 51: 103-106, 1979

5) Mehdorn HM, Chater NL, Townsend JJ, Darroch JD, Perkins RK, Lagger R: Giant aneurysm and cerebral ischemia. Surg Neurol 13: 49-59, 1980

6) Heiskanen O: Risk of bleeding from unruptured aneurysm 
incase with multiple intracranial aneurysms. J Neurosurg $\mathbf{5 5}$ : 524-526, 1981

7) Salazar JL: Surgical treatment of asymptomatic and intracranial aneurysms. J Neurosurg 53: 20-21, 1980
8) Wiebers DO, Whisnant JP, O'Fallon WM: The natural history of unruptured intracranial aneurysms. N Engl J Med 304: $696-698,1981$ 